\title{
Effect of Macroeconomic Variables on the FDI inflows: The Moderating Role of Political Stability: An Evidence from Pakistan
}

\author{
Arfan Shahzad ${ }^{1} \&$ Abdullah Kaid Al-Swidi ${ }^{1}$ \\ ${ }^{1}$ Othman Yeop Abdullah Graduate School of Business, University Utara Malaysia, Malaysia \\ Correspondence: Abdullah Kaid Al-Swidi, Othman Yeop Abdullah Graduate School of Business, University \\ Utara Malaysia, Malaysia. Tel: 60-12-466-2754. E-mail: swidi@uum.edu.my
}

Received: April 5, 2013 Accepted: May 26, 2013 Online Published: June 29, 2013

doi:10.5539/ass.v9n9p270

URL: http://dx.doi.org/10.5539/ass.v9n9p270

\begin{abstract}
This study has examined the moderating role of Political Stability (PS) on the relationships between macroeconomic variables and the Foreign Direct Investment (FDI) inflows in Pakistan. For that purpose, this study used the authentic annual data for the period 1991 to 2011. The empirical analysis involved using the ADF test to check the stationary of the data, the EViews software and hierarchal regression using SPSS 19.0 statistical software package. The results of the study confirmed that that GDP growth rate, exports, imports and balance of payment have positive significant effects on FDI inflows in Pakistan. On the other hand, the inflation rate was not significant in determining the FDI inflows in the country. However, the GDP growth rate and Balance of Payment tends to be a significant determinant of FDI inflows when the moderating effect of the Political stability is accounted for. Based on the findings of this study, it is strongly suggested that political stability is crucial for the country's domestic and foreign investment expansion in the future course of direction.
\end{abstract}

Keywords: FDI Inflows, political stability, balance of payment, imports, export, inflation rate, GDP growth rate

\section{Introduction}

In the modern era of $21^{\text {st }}$ century, it has been vehemently emphasized that Foreign Direct Investments (FDIs) confer several economic such as, capital inflows adding to the reserves, thus, improving the balance of payments, increasing the exports and causing exports-led growth, fostering innovation and modern technologies, new style of management skills, increasing the jobs and employment opportunities in the host country (Salman \& Feng, 2010; Javed et al., 2012; Shahzad et al., 2012). Several researchers have also highlighted the importance of foreign direct investment in the sense that it can stimulate the domestic investors to invest further in the country (Awan, Khan, \& Us-Zaman, 2011; Brooks \& Sumulong, 2003). Time and again, developed countries as well as developing countries have been offering a lot of attractive packages to attract foreign investment inflows as an increasing rate. The countries such as, China, India, Russia and Barizal (BRIC economy segment) are offering lucrative packages of incentives to foreign companies, such as, low tax rate, cheap labor, export zone facilities, liberalized trade policy, market orientation of the economy, good infrastructure, good order of law and security system. In the new economic order of the globalization era, the foreign direct investment(FDI) is considered to be a major contributor to the economic growth of any developed and developing economy (see, World Development Report, 2011). Since 1990s, foreign direct investment (FDI) emerged as a boon to developing countries in promoting industrialization, growth and development. It is interesting enough to compare the growth trends of trade and investment in perceiving the dynamics of international business in the world economy in the years corresponding to a new millennium era. A rising trend of FDI inflows in the newly emerging segments of the developing world economy is attributed to the perception that such inflows trend to help in augmenting the productive resources and filling up a technological gap and overcoming capital shortage to facilitate the growth process of development in upcoming of the developing countries in recent years.

Since foreign direct investment (FDI) is assumed to be a major source of foreign capital for industrialization and growth process in a developing country, it is virtually regarded as an engine of growth and economic expansion in the global economic arena. Over the years, however, FDI inflows have tended to be comparatively much less in developing countries and largely been confined to developed countries as is evident from the data in Table 1 . As a matter of fact, however, several developing countries and especially countries like Pakistan have been facing the problem of saving-investment gap, as such foreign direct investment is assumed to be vitally 
influencing factor in the process of economic growth by filling up this gap through modern technology transfer, and productive resource exploitation (Kobrin, 2005; Ataullah, Cockerill, \& Le, 2004). In Pakistan, especially, the total investment (domestic and foreign investment) and corresponding capital formation has been going down in recent years 2008 to 2011 (and even in 2012) and FDI inflows is at a much lower level as compared to the neighboring countries such as India, Sri Lanka, Malaysia and Bangladesh (UNCTAD, 2011).

Moreover, during the period of last two decades Pakistan's economic growth rates have been a fluctuating phenomenon. After a remarkable economic GDP growth rate of $7.57 \%$ in 1991, economic growth rate of Pakistan decreased to $2.1 \%$ in 2000 . The country's GDP implied a decreasing trend during the period from 2007 to 2011. Pakistan foreign trade has always remained to be lopsided. The country's imports have been increasingly in excess of the exports leading to expanding current account deficits (CAD) in the BOP. As such, the government of Pakistan has consistently faced the problem of adverse balance of payment. A fuel to the flame is added when inflation rate which was $3.6 \%$ in 2001 has tended to be $13.8 \%$ in 2011 (Iqbal, Shaikh, \& Shar, 2010; Javed et al., 2012).

Table 1. Foreign direct investment inflows during the period of 1991- 2011 (Millions of U. S. dollars)

\begin{tabular}{lrrrrrrrrrrr}
\hline & $\mathbf{1 9 9 1} \mathbf{2 0 0 1}$ & $\mathbf{2 0 0 2}$ & $\mathbf{2 0 0 3}$ & $\mathbf{2 0 0 4}$ & $\mathbf{2 0 0 5}$ & $\mathbf{2 0 0 6}$ & $\mathbf{2 0 0 7}$ & $\mathbf{2 0 0 8}$ & $\mathbf{2 0 0 9}$ & $\mathbf{2 0 1 0}$ & $\mathbf{2 0 1 1}$ \\
\hline World & 869,122 & 817,574 & 716,128 & 559,576 & 710,755 & 958,697 & $1,411,018$ & $1,833,324$ & $15,294,653$ & $17,950,498$ & $19,140,603$ \\
Developed & 491,856 & 571,483 & 547,778 & 366,573 & 396,145 & 611,283 & 940,861 & $1,247,635$ & $10,616,230$ & $12,263,733$ & $12,501,569$ \\
countries & & & & & & & & & & & \\
Developing & 172,364 & 219,721 & 155,528 & 172,033 & 275,032 & 316,444 & 412,990 & 499,747 & $4,441,301$ & $5,060,116$ & $5,951,203$ \\
countries & & & & & & & & & & & \\
Asia & 97,502 & 111,966 & 92,009 & 107,278 & 156,622 & 210,572 & 274,291 & 320,489 & 608,492 & 769,542 & 916,972 \\
ASEAN & 24,391 & 19,601 & 14,507 & 17,364 & 25,666 & 39,091 & 51,243 & 60,514 & 173,976 & 220,008 & 260,980 \\
Pakistan & 2082 & 484 & 798 & 949 & 1524 & 3521 & 5410 & 5140 & 3720 & 2206 & 1739 \\
\hline \multicolumn{1}{l}{ Sour }
\end{tabular}

Sources: IMF (2003) p.10, and UNCTAD, World Investment Reports, 2011, SBP, Handbook of Statistics on Pakistan Economy, 2011 p.556.

The dismal economic situation of Pakistan may be specifically attributed to the downfall of the nation's political stability and increased corruption in the government sector, leading to biggest security threats in the business environment in Pakistan (Shahzad et al., 2012). Pakistani policy makers have neglected to business environmental consider major issues, such as, poor state of infrastructure, energy shortages, inflation, corruption, rule of law and security in the country. There is glaring research gap relating to in-depth analysis of the major issues and policy guidelines which the present study sought to fill up by examining the case of a developing country such as Pakistan.

\section{Motivation of the Study}

The present study in general seeks to probe whether the economic growth rate scenario of the country truly reflects the steps of reforms undertaken by the Pakistani policy makers over the years have gone into the right directions. It is disheartening to note that the economic growth rate of the Pakistani national economy had been receeding since 2008 onwards due to several controllable and non-controllable interactive factors including biggest natural flood in the history of Pakistan, worsening balance of payments (BOP) due to the rising current account deficits (CAD), political party's rivalry issues and absence of competitively attractive economic policies in inducing investment and business activity. Pakistani currency has started depreciating since 2007 until today (2012) against the US dollar. Incidentally, the dismal economic situation has a dent in causing the low level and declining trend of FDI in Pakistan economy. Data in Figure 1 explicitly reveals that foreign direct investment in Pakistan has been declining since 2008 to 2012. By the way, in Pakistan political stability is worse compared to the some neighboring Asian countries such as India, China and Malaysia. For the country like Pakistan in the take off stage of a developing shortage of capital may affect her growth rate. Pakistani policy makers need to revamp the business friendly investment policies. 


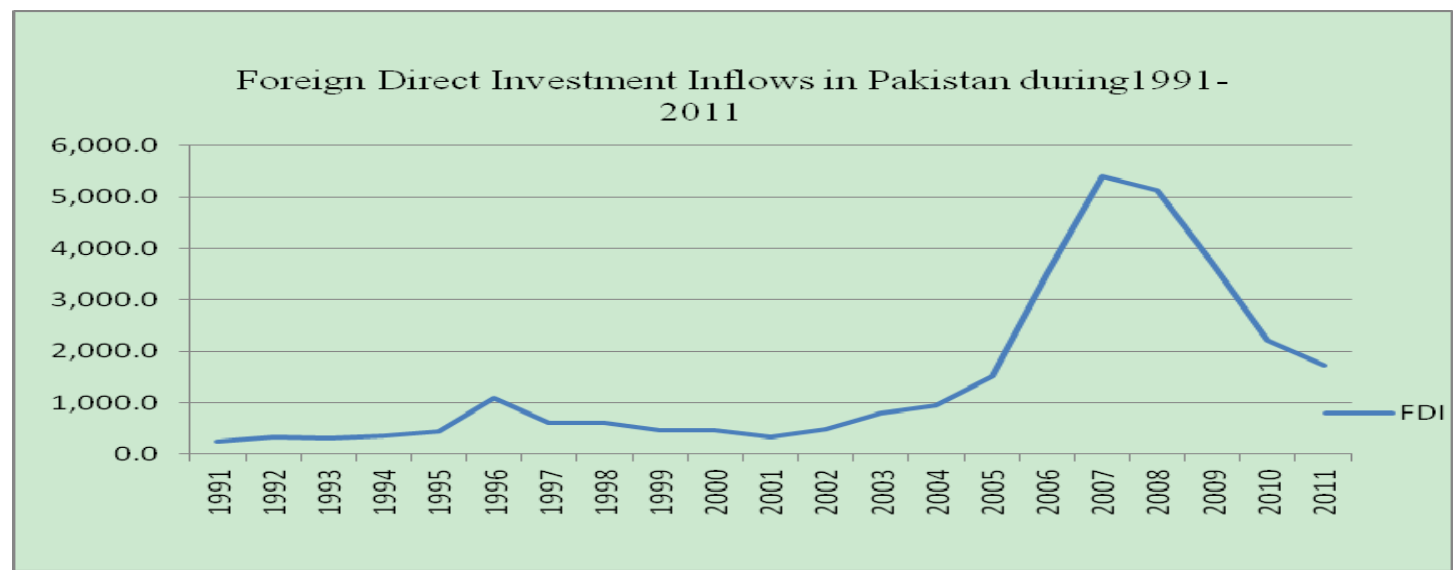

Figure 1. Pakistan FDI inflow during the period 1991-2011

Source: SBP, Handbook of Statistics on Pakistan Economy, 2011 p.556.

Over the years, while in India FDI inflows has been increasing since last 10 years and in the same region in Pakistan these is declining foreign investment flows over the years (Shahzad et al., 2012). According to UNCTAD (2007), thus, India has come forward as one of the most attractive country for FDI after China, USA, Russia and Brazil. This may be attributed to the obvious fact that Indian policy makers have been continually making concerted efforts to pose India as an attractive destination for foreign direct investment. Pakistan needs to learn much from the Indian economic policies and vision. The present study, thus, seeks to investigate why in Pakistan FDI inflows have declined over the years since 2008 and what policy strategy can be envisaged for the future course of direction. In a recent study (Shahzad et al., 2012) suggested that there is a need to empirically investigate the macroeconomic variables on FDI inflows in Pakistan with the moderating role of political Stability in order to get the clear picture of the country growth and the role of political stability as the most influencing factor among the macroeconomic variables.

\section{Determinants of FDI Inflows}

Akhtar (2000) conducted a study in Pakistan using the FDI inflows as dependent variable and independent variables such as GDP growth rate, Imports, Exports, Exchange rate, Interest rate, political instability and military rule. The study observed that Wang (2009) pinpointed on inward foreign direct investment (FDI) and economic growth in 12 Asian economies referring to data over the period of 1987 to 1997 in the course of empirical investigation. Wang (2009), however, also observed that FDI inflows in nonmanufacturing sectors do not play a significant role in enhancing economic growth. In a recent study Awan (2010) has examined the effect of determinants of FDI in the country analyzing FDI flows during the period 1971-2008. Foreign Direct Investment (FDI) in Pakistan can play a vital source of external capital flows to fulfill the saving-investment gap and increasing the volume of exports and reduce the imports as well. Awan (2010)'s study has detected that among the determent variables of degree of openness (DOP), Inflation rate (INFRATE) is statistically significant with positive signs with FDI inflows in Pakistan, whereas the Balance of Payment (BOP) also shown statically significant with a negative sign. The independent variable of GDP and Debt servicing is found to be not significant in its impact on FDI inflows in Pakistan. Likewise, Shahzad et al. (2012) also traced the impact of macro variables such as GDP, growth rate, DOP, Infrastructure, rule of laws and labor wages on FDI inflows in Pakistan. The present study considers the FDI inflows as the dependent variable in relation to several economic determinants as discussed below.

\subsection{GDP Growth Rate}

The GDP growth rate is very important for any country for foreign investor to make decisions for investment. However, GDP growth rate and FDI inflows and vice versa is always a main track of focus assumed by the researches in economic literature. The study of Martinez-Zarzoso (2003) concluded that high levels of growth in the host country indicates a high level of production that enhances the confidence level of investors. On the other hand, the research of Martinez-Zarzoso and Nowak-Lehmann (2004) also suggested that the higher income in home countries attracts the foreign investor interest to invest in that country. The GDP growth rate is considered as the national income growth indicator of the economic performance of the country, which is reflected through production, consumption, and varieties of goods and other economic facilities provided in the country. In 
Pakistan, however, GDP growth rate has been declining during the period 2001-2011(Qaiser et al., 2011).

Fundamentally, macroeconomic factors conditions are expected to exert influence on FDI. Gross and Trevino (1996) highlighted that countries possessing a higher GDP growth rate are expected to promote a large dose of FDI, inducing future Multinational Companies (MNCs) with high confidence to invest, especially, when growth trend is more consistent. High economic growth rates are likely to lure investors in finding the market potential for higher return values on investments which are confined to higher levels of FDI (Biglaiser \& DeRouen, 2011). On this count, the following hypothesis is proposed to be empirically investigated.

\section{H1. There is a positive relationship between GDP growth rate and FDI inflows.}

\subsection{Exports}

Exports can be regarded as an indicator of the country's export-led growth and improvement in the Balance of Payment and a factor to stabilize the exchange rate. A few researchers have indicated that the volumes of exports by country tend to attract the FDI inflows (Navaretti, Venables, \& Barry, 2004; Markusen \& Maskus, 2002). Going through the literature in the case of developing countries such as India in the neighborhood of Pakistan one may come a prominent study of Jayachandran and Seilan (2010) having investigated the relationship between import and exports, FDI and economic growth of India during the period of 1970-2007. The study concludes that import, exports and economic growth posited to have a positive causal relationship with FDI inflows. On the other hand, few researches such as (Liu et al., 2002) have traced the relationship between FDI, exports and imports in China use the methods developed by Hall and Milne (1994) and have detected significant positive impact of foreign trade on FDI inflows. As such, it is proposed to examine the following hypothesis in the context of Pakistan:

\section{H2. There is a relationship between Exports and FDI inflows.}

\subsection{Balance of Payment}

In the literature, it is well conceived that economic FDI inflows tend to improve the balance of payment position of the host country. The study conducted by Majeed and Eatazaz (2009) highlighted the characteristics of those host countries which are basics in taking decisions regarding the location of Multinational companies (MNs) in developing countries. The study used the panel data from 72 developing countries for the period 1970-2008. The study results reveal that the balance of payment and inflation has negative significant influence on FDI inflows. We, thus, resort to lay down the following hypothesis.

\section{H3. There is a relationship between Balance of Payment (BOP) and FDI inflows.}

\subsection{Imports}

In the economic literature, it is presumed that countries with high imports from abroad tend to attract FDI (Mundell, 1957). The study of Geweke's (1982) found a positive relationship between Imports and FDI inflows in USA. The researchers argued that more imports in the host country considered to be a pointer on the potential market for the intended exports of the home country firms. In fact, the companies may assume that it is better to produce locally in order to satisfy domestic demand of the host country markets. Indeed, foreign entries might visualize the various routes of servicing the host country's market before undertaking FDI decision ultimately. Aizenman and Noy (2005) have traced positive relationship between imports and FDI inflows. However, it is necessary but difficult to measure that inflows of FDI have different effects on imports of different types of goods. We may, however, laid down the following hypothesis.

\section{H4. There is a relationship between Imports and FDI inflows.}

\subsection{Inflation Rate}

Inflation rate is an important feature of a country's good economic fundamentals. Rate of inflation is regarded as a crucial factor in influencing the FDI inflows. The high rates of inflation imply economic instability of the country. By and large, high rates of inflation are associated with the lesser FDI inflows. Akinboade et al. (2006) have concluded that low inflation is a sign of internal economic stability in the country. The study of Awan and uzZaman (2010) revealed that inflation rates caused positive significant effect of the FDI inflows in Pakistan. Similarly, another study of Zaman et al. (2006) also found that inflation rate have positive significant impact on FDI inflows in Pakistan. But the differences between "high" inflation and "low" inflation are not distinct when inflation is just viewed as purely a monetary phenomenon (Ahn \& Willett, 1998). As such we propose the following hypothesis in the context of Pakistan for investigation.

\section{H5. There is a relationship between Inflation Rate and FDI inflows.}




\section{Political Stability and FDI Inflows}

Political stability is very important for normal macroeconomic balance and conducive business environment in a country. Political risks largely depend on political stability and good governance of the government (Husain, 2009, Shahzad et al., 2012). In a recent study Shahzad et al. (2012) argues that the political stability enhances the probability of attracting more FDI inflows into the developing countries. The country like Pakistan has been continually suffering from the instability of the political system, thus, will adversely affect the level of foreign and domestic investment in the country. Of course, Political instability is not good since it will adversely affect the country's economic development and growth process by its unhealthy dent on the physical and human resources. When the country's Political Stability condition is not good, foreign investors will hesitate to bring any projects until they are assured that the business environment would be conducive and favorable (Brada et al., 2005; UNCTAD, 2010; Word Bank, 2011). In the case of Pakistan, World Bank report, published in 2011 categorically mentioned that the private sector's low investment in the country is largely attributed to the situation of political instability and corruption.

Indeed, determinants of political risks such as change of regime, government intervention in the economic situations, property rights legislation, and red tape may adversely affect the decision process of foreign investments (Frey \& Schneider, 1979). However, the international investors and the international organizations give high importance for their FDI decision process on how good is the governance index of each country such as: fighting corruption; transparency of the administration processes; and violence free environment (World Bank, 2006). According to Shahzad et al. (2012), suggested that macroeconomic determinant affect by political stability. The following hypotheses are formulates, thus:

H6: Political Stability moderates the relationship between GDP growth rate and the FDI inflows in Pakistan.

H7: Political Stability moderates the relationship between Exports and the FDI inflows.

H8: Political Stability moderates the relationship between Inflation Rate and the FDI inflows.

H9: Political Stability moderates the relationship between Imports and the FDI inflows.

H10: Political Stability moderates the relationship between Balance of Payment and the FDI inflows.

\section{Research Framework and Variable Measurements}

For determining the course of empirical investigation, the following research framework is devised to tracing the impact of various types of selective Macroeconomic variables and Business environment variables to attract FDI in Pakistan linking with moderating role of political stability during 1991-2011.

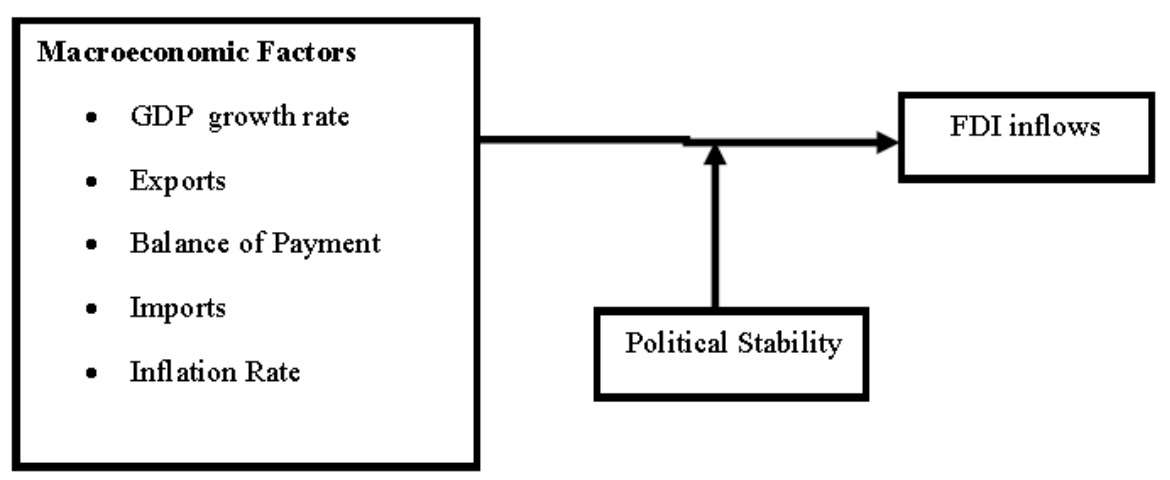

Figure 2. Research framework

The following variables have been incorporated in the empirical investigation process of the study.

FDI inflows $=$ Foreign Direct Investment inflows on a yearly basis (data will collected from the State Bank of Pakistan).

GDPGR $=$ Gross domestic production growth rate (data will be collected from the Stat bank of Pakistan).

Exports $=$ Total exports of the country reported in UNCTAD or Sate Bank of Pakistan.

Imports $=$ Total imports of the country reported in UNCTAD or Sate Bank of Pakistan.

Inflation Rate $=$ consumer price index change in years

Balance of Payment $=$ Balance of Payment is meant to determine the ability to pay for the foreign trade. 
PSI = Political Stability Index (collected from the World Bank Indicator reports).

\section{Data Analysis and Results}

To investigate the effects of macroeconomic variables on the FDI inflows in Pakistan as well as the moderating role of political stability as discussed in the hypotheses development and illustrated in the research framework, this study followed the following steps.

\subsection{Units Root Tests (ADF Test)}

In order to avoid spurious regression, we begin with an investigation of the properties of the time series data that we are dealing with to determine if the variables are stationary or nonstationary in nature. The procedure used here is the Augmented Dickey Fuller (ADF). Data in Table 2 shows that dependent variable of FDI inflows and other variables of macroeconomic variables such as, GDPGR, Exports, Inflation rate, imports and FDI and Political stability (PSI) are stationary.

Table 2. ADF unit root test result using the trend and intercept

\begin{tabular}{lllll}
\hline & Variable & $1^{\text {st }}$ Diff & $2^{\text {nd }}$ Diff & Lagged \\
\hline 1 & FDI & 0 & $\mathrm{~S}$ & 2 \\
2 & GDPGR & 0 & $\mathrm{~S}$ & 1 \\
3 & Exports & 0 & $\mathrm{~S}$ & 1 \\
6 & Inflation & $\mathrm{S}$ & - & 1 \\
7 & Imports & 0 & $\mathrm{~S}$ & 1 \\
8 & BOP & $\mathrm{S}$ & - & 1 \\
9 & PSI & $\mathrm{S}$ & - & 1 \\
\hline
\end{tabular}

\subsection{Regression Analysis Results for Predictor Power}

After all the regression assumptions were checked and found to be satisfied, this study ran the regression analysis using SPSS 19.0 to examine the predictive power of the hypothesized model. Moreover, it was used to identify and compare the predictive power of the dimensions of macroeconomic variables namely, GDPGR, Exports, Inflation Rate, Imports and BOP. Based on the results in Table 3, it can be concluded that GDPGR $(\beta=0.288, \mathrm{t}=3.067, \mathrm{p}<0.05)$, Exports $(\beta=1.306, \mathrm{t}=2.351, \mathrm{p}<0.05)$, imports $(\beta=2.090, \mathrm{t}=3.361, \mathrm{p}<0.05)$ and $\mathrm{BOP}$ $(\beta=0.362, t=3.191, p<0.05)$ have significant positive impact of the FDI inflows at 0.05 levels of significance. In addition, the results revealed that GDPGR, Exports, Imports and Balance of Payment had greater impact on the FDI inflows in Pakistan. These results, however, supported the hypotheses H1, H2, H4 and H5. The Inflation Rate was not significant determinants of the FDI inflows in the case of Pakistan.

Table 3. Examining variables' predictive power

\begin{tabular}{lll}
\hline Variables & Beta & T value \\
\hline GDPGR & $0.288^{* *}$ & 3.067 \\
Exports & $1.306^{* *}$ & 2.351 \\
INFRATE & -0.202 & -1.854 \\
Imports & $2.090^{* *}$ & 3.361 \\
BOP & $0.362^{* *}$ & 3.191 \\
F value & & 11.982 \\
F Sig. & & 0 \\
$\mathrm{R}^{2}$ & & 0.920 \\
Adjusted $\mathrm{R}^{2}$ & & 0.893 \\
Durbin Watson & & 2.353 \\
\hline
\end{tabular}

$* * *: \mathrm{p}<0.01 ; * *: \mathrm{p}<0.05$ 


\subsection{Hierarchical Regression Analysis to Examine the Moderating Effect}

The hierarchical regression results were reported according to the analysis stages. First, this study examined the moderating effect of Political stability on the above mentioned relationships following the method of Frazier, Tix, and Barron (2004). In this model, the interaction terms between the macroeconomic variables, business environment variables and political stability were examined to test the moderating effect. The results in Table 4 indicate that GDPGR and balance of payment variables were significant predictors of the FDI inflows at the 0.05 level of significance.

Table 4. Examining the moderating effect of political stability

\begin{tabular}{lllllll}
\hline Variables & Predictors & T value & Moderated & T value & Interactions & T value \\
\hline GDPGR & $0.288^{* *}$ & 3.067 & $0.252^{* *}$ & 2.900 & $0.215^{* *}$ & 3.054 \\
Exports & $1.306^{* *}$ & 2.351 & $1.862^{* *}$ & 3.259 & 0.231 & 0.284 \\
INFRATE & -0.202 & -1.854 & -0.024 & -0.179 & -0.036 & -0.279 \\
Imports & $2.090^{* *}$ & 3.361 & $1.884^{* *}$ & 3.290 & -0.064 & -0.067 \\
BOP & $0.362^{* *}$ & 3.191 & $0.397^{* *}$ & 3.806 & 0.225 & 1.1638 \\
PSI & & & 0.723 & 2.061 & 0.221 & 0.821 \\
GDP_PSI & & & & $0.388^{* *}$ & 3.887 \\
Exports_PSI & & & & 0.923 & 2.157 \\
Infrate_PSI & & & & 0.112 & 0.941 \\
Imports_PSI & & & & -1.513 & -2.348 \\
BOP_PSI & & & & $0.297^{* *}$ & 2.318 \\
F value & & & 35.5 & & 45.1 \\
F Sig. & & 0 & 0 & & 0 \\
R2 & 0.92 & & 0.939 & & 0.982 \\
Adjusted R2 & 0.893 & & 0.912 & & 0.96 \\
R2 change & 0.92 & & 0.19 & & 0.044 \\
Significant F change & & 0 & 0.058 & & 0.026 \\
\hline
\end{tabular}

$* * *: \mathrm{p}<0.01 ; * *: \mathrm{p}<0.05$

Data in Table 4 represent the examination of the interaction terms between of political stability and macroeconomic variable, business environment. While the interaction term between GDPGR and balance of payment (BOP) was found to be significant at the 0.05 level of significance GDPGR $(\beta=0.215, \mathrm{t}=3.054, \mathrm{p}<0.05)$ and $\operatorname{BOP}(\beta=0.297, \mathrm{t}=2.318, \mathrm{p}<0.05)$ the interaction terms between the macroeconomic variables GDPGR and BOP and Political stability was found significant. These results indicate that political stability positively and significantly moderates the effect of GDPGR and Balance of Payment on FDI inflows. This result, however, supported the hypotheses $\mathrm{H} 6$ and $\mathrm{H} 10$.

\subsection{Discussions, Conclusion and Recommendations}

The empirical findings of this study are based on the analysis pertaining to 21 years data for the period 1991 to 2011 relating to FDI inflows in Pakistan. To test the hypotheses of this study, in particular hierarchical multiple linear regression was employed. The results of the study imply that some of the hypotheses are supported. In particular, the hypotheses H1, H2, H4, and H5 are supported with FDI inflows in Pakistan, whereas like H3 is not supported. In examining the moderating effects of political stability with microeconomic variables in FDI inflows (the Hypothesis $\mathrm{H} 6$ and $\mathrm{H} 10$ are supported). It is established that the political stability is very important among other factors for foreign investment in the case of Pakistan. The result findings further asserted that GDP growth rate and balance of Payment nexus depends on the country's stable political situation.

Consistent growth of GDP is the good sign for any economy, which will attract the foreign investor to invest in the concerned country. The GDP growth rate is also very important determinant for the FDI. Exports also attract the foreign investment to the country. Pakistan policy makers should support the export-oriented FDI into the 
country. Pakistan needs to provide the attractive packages for high tech companies to invest in the county. High tech companies' production in Pakistan can facilitate her exports to others neighboring countries. Pakistani Policy makers should learn further lessons from the experience of Malaysia, Thailand and India. Exports oriented FDI will bring to country lot of benefits such as new opportunity for jobs, latest technology, and enhancement of the human capital, super Knowledge management, stronger the exchange rate and improvement of the balance of payments in the country. It is high time that Pakistani policy makers should seek to increase the volume of exports and try to decrease the Imports. In the current situation, Pakistan exports are much lower than imports. The country should improve her BOP position by all means. Strong Balance of Payment also attracts the foreign investment to the country. The present study focused on and highlighted the moderating role of political stability for macroeconomic stability. The country's good infrastructure, stable political system, strong balance of payments and trade policy will affect her economic growth. Furthermore, the Pakistani government needs to develop good infrastructure to attract the foreign investment. In the case of Pakistan, however, political stability ranking is not good compared to other developing countries such as Malaysia, China and India. Pakistani policy makers therefore need to establish the rule of law in the country to protect the foreign investment and demonstrable the symptoms of political stability.

By and large, this study examined the empirical parameters of the foreign direct investment inflows in Pakistan during the period 1990-2011. To arrest the declining trend of FDI in the country, we may suggest that policy-makers of Pakistan need to revamp the FDI policy to attract more investment into the country. Selective FDI policies may be spelt-out by the Pakistani Policy makers to channelize FDI inflows in much warranted direction by including a set of positive and negative lists of action. Positive list is meant to refer to sectors in which the FDI inflows are encouraged. Negative list implies indicating sectors in which the FDI inflows in need to be disallowed such as defense good and the service sector, for instance. The approval procedure and screening mechanism should be adequately decided to meet the FDI policy objective. A developing country such as Pakistan need to design its FDI policy contents thoughtfully well in promoting its goal of growth with macroeconomic balancing and policy flexibility, time and again, in pragmatic determination of FDI inflows in the future course of direction. One of the main suggestions for future research is to examine in-depth the moderating impact of the political stability on the relationship between various macroeconomic balancing and business environmental factors and FDI inflows.

\section{References}

Ahn, D. Y. S., Adji, D. S. S., \& Willett, D. T. D. (1998). The effects of inflation and exchange rate policies on direct investment to developing countries. International Economic Journal, 12(1), 95-104.

Aizenman, J., \& Noy, I. (2005). FDI and trade-Two-way linkages? The Quarterly Review of Economics and Finance, 46(3), 317-337. http://dx.doi.org/10.1016/j.qref.2006.02.004

Akhtar, M. H. (2000). The Determinants of Foreign Direct Investment in Pakistan: An Econometric Analysis. The Lahore Journal of Economics, 5(2), 1-22.

Akinboade, O. A., Siebrits, F. K., \& Roussot, E. N. (2006). Foreign direct investment in South Africa. Foreign Direct Investment.

Ataullah, A., Cockerill, T., \& Le, H. (2004). Financial liberalization and bank efficiency: a comparative analysis of India and Pakistan. Applied Economics, 36(17), 1915-1924. http://dx.doi.org/10.1080/000368404200068638

Awan, M. Z., Khan, B., \& Uz Zaman, K. (2011). Economic determinants of Foreign Direct Investment (FDI) in commodity producing sector: A case study of Pakistan. African Journal of Business Management, 5(2), 537-545.

Awan, M. Z., Uz Zaman, K., \& Khan, B. (2010). Determinants of Foreign Direct Investment In Services Sector Of Pakistan: An Econometric Approach. Global Financial Crisis: Causes, Emerging Trends and Strategy, 5(2), 167.

Biglaiser, G., \& DeRouen, K. (2011). How soon is now? The effects of the IMF on economic reforms in Latin America. The Review of International Organizations, 1-25.

Brada, J. C., Kutan, A. M., \& Yigit, T. M. (2005). The effects of transition and political instability on foreign direct investment in ECE emerging market. Paper presented at the United Nations Economic Commission for Europe (UNECE) Spring Seminar.

Brooks, D. H., Fan, E. X., Sumulong, L. R., \& Bank, A. D. (2003). Foreign direct investment in developing Asia: 
trends, effects, and likely issues for the forthcoming WTO negotiations. Asian Development Bank.

Frazier, P. A., Tix, A. P., \& Barron, K. E. (2004). Testing moderator and mediator effect in counseling research. Journal of Counselling Psychology, 51(1), 115-134. http://dx.doi.org/10.1037/0022-0167.51.1.115

Geweke, J. F. (1982). Measures of conditional linear dependence and feedback between time series. Journal of the American Statistical Association, 79(388), 907-915. http://dx.doi.org/10.1080/01621459.1984.10477110

Hall, S., \& Milne, A. (1994). The relevance of P-star analysis to UK monetary policy. The Economic Journal, 104, 597-604. http://dx.doi.org/10.2307/2234634

Husain, I. (2009). The Role of Politics in Pakistan's Economy. Journal of International Affairs, 63(1), 1-18.

Iqbal, M. S., Shaikh, F. M., \& Shar, A. H. (2010). Causality Relationship between Foreign Direct Investment, Trade and Economic Growth in Pakistan. Asian Social Science, 6(9), 82.

Javed, K., Falak, S., Awan, R., \& Ashfaq, M. (2012). Foreign Direct Investment, Trade and Economic Growth: A Comparison of Selected South Asian Countries. International Journal of Humanities and Social Science, 2(5).

Jayachandran, G., \& Seilan, A. (2010). A causal relationship between Trade, Foreign Direct Investment and Economic Growth for India. International Research Journal of Finance and Economics, 42, 74-88.

Kobrin, S. J. (2005). The determinants of liberalization of FDI policy in developing countries: A cross-sectional analysis, 1992-2001. Transnational Corporations, 14(1), 67-104.

Liu, X., Burridge, P., \& Sinclair, P. J. N. (2002). Relationships between economic growth, foreign direct investment and trade: evidence from China. Applied Economics, 34(11), 1433-1440. http://dx.doi.org/10.1080/00036840110100835

Majeed, M. T., \& Ahmad, E. (2009). An Analysis of Host Country Characteristics that Determine FDI in Developing Countries: Recent Panel Data Evidence. The Lahore Journal of Economics, 14(2), 71-96.

Markusen, J. R., \& Maskus, K. E. (2002). Discriminating among Alternative Theories of the Multinational Enterprise. Review of International Economics, 10, 694-707. http://dx.doi.org/10.1111/1467-9396.00359

Martanez-Zarzoso, I., \& Nowak-Lehmann, F. D. (2004). Economic and geographical distance: Explaining Mercosur Sectoral Exports to the EU. Open Economies Review, 15(3), 291-314. http://dx.doi.org/10.1023/B:OPEN.0000037702.33704.20

Martinez-Zarzoso, I. (2003). The log of gravity revisited. Applied Economics, 45(3), 311-327. http://dx.doi.org/10.1080/00036846.2011.599786

Mundell, R. A. (1957). International trade and factor mobility. The American Economic Review, 47(3), 321-335.

Navaretti, G. B., Venables, A., \& Barry, F. (2004). Multinational firms in the world economy. Princeton Univ Press.

Qaiser Abbas, S. A., Nasir, A. S., Ullah, H. A., \& Muhammad, A. N. (2011). Impact of Foreign Direct Investment on Gross Domestic Product (A Case of SAARC Countries). Global Journal of Management and Business Research, 11(8).

Salman, A., \& Feng, H. X. (2010). FDI in Pakistan: Impact on GNP and capital financial account. Paper presented at the Financial Theory and Engineering (ICFTE).

SBP. (2004). State bank of Pakistan Annual Report.

SBP. (2005). State bank of Pakistan Annual Report.

SBP. (2011). State Bank of Pakistan Annual Report.

Schneider, F., \& Frey, B. S. (1985). Economic and political determinants of foreign direct investment. World development, 13(2), 161-175. http://dx.doi.org/10.1016/0305-750X(85)90002-6

Shahzad, A., Mithani, D. A., Al-Swidi, A. K., \& Fadzil, F. H. (2012). Political Stability and the Foreign Direct Investment Inflows in Pakistan. British Journal of Arts and Social Sciences, 9(2) 199-213.

UNCTAD. (2010). World Investment Report. United Nations, New York.

UNCTAD. (2011). World Investment Report. United Nations, New York.

UNDP. (2004). National Human Development Report.

United Nations. (2000). UN Demographic Yearbook Historical Supplement. Statistics Division, Department of 
Economic and Social Affairs, the United Nations.

Wang, M. (2009). Manufacturing FDI and economic growth: evidence from Asian economies. Applied Economics, 41(8), 991-1002. http://dx.doi.org/10.1080/00036840601019059

World Bank Report. (2011). United State, New York.

Zaman, K., Shah, I. A., Khan, M. M., \& Ahmad, M. (2006). Macroeconomic Factors Determining FDI Impact on Pakistan's Growth. South Asian Journal of Global Business Research, 1(1), 6-6.

\section{Copyrights}

Copyright for this article is retained by the author(s), with first publication rights granted to the journal.

This is an open-access article distributed under the terms and conditions of the Creative Commons Attribution license (http://creativecommons.org/licenses/by/3.0/). 